\title{
DIE KEURING VAN KANDIDATE VIR TEOLOGIESE OPLEIDING: NOODSAAK EN TOEPASSING
}

Authors:

Frank T. Cooke ${ }^{1,2}$

Malan $\mathrm{Nel}^{1}$

\section{Affiliations:}

${ }^{1}$ Department of Practical Theology, University of

Pretoria, South Africa

\section{${ }^{2}$ Nederduitse}

Gereformeerde Kerk,

Potchefstroom

South Africa

\section{Correspondence to:}

Frank Cooke

email:

terencecooke@telkomsa.net

Postal address:

PO Box 5207, Kockspark

2523, South Africa

\section{Keywords:}

Theological training; candidate; selection competence; capability; suitability

\section{Dates:}

Received: 15 Jan. 2010

Accepted: 07 Apr. 2010

Published: 25 Aug. 2010

How to cite this article Cooke, F.T. \& Nel, M., 2010, 'Die keuring van kandidate vir teologiese opleiding: Noodsaak en toepassing', HTS Teologiese Studies/Theological Studies 66(2), Art. \#828, 6 pages. DOI: 10.4102/hts.v66i2.828

This article is available at: http://www.hts.org.za

C 2010. The Authors. Licensee: OpenJournals Publishing. This work is licensed under the Creative Commons Attribution License.

\section{ABSTRACT}

The selection of candidates for theological training: Necessity and application The selection of candidates for theological training is a sensitive issue, as many see it as a verdict on the authenticity of the prospective student's claim of having been called to ministry by God. This article argues that, in addition to a sense of calling, the profile of a candidate should include abilities in terms of office (power), profession (capability) and person (adequacy). The process of selection should involve all these aspects. The guidelines of the Dutch Reformed Church in South Africa in this regard in its publication, $A-Z$ Handleiding aangaande predikante van die Nederduitse Gereformeerde Kerk, are discussed. The selection process should not be seen as a test of the authenticity of candidates's sense of calling, but rather as a way in which candidates can be guided to discern their calling and place within the body of Christ. A positive outcome in the areas of office, capability and adequacy could confirm the claim of having been called by God. The article concludes that the selection of candidates for theological training is not a single event, but a process that starts when the prospective candidate reports to the church council, and is completed with the pastor's ordination by the church.

\section{INLEIDING}

Die keuring van kandidate vir teologiese opleiding is 'n uiters sensitiewe saak. Die grootste rede hiervoor is dat die predikant as 'n persoon met ' $n$ 'roeping van God' beskou word, en dat keuring sou impliseer dat mense hulle oor die geldigheid van ' $n$ ander se baie intieme en persoonlike ervaring met God uitspreek. Hierdie artikel toon dat die profiel van die predikant, benewens sy of haar roeping, ook uit die amp (bevoegdheid), beroep (bekwaamheid) en persoon (geskiktheid) bestaan. Keuring met die oog op teologiese opleiding handel oor al hierdie aspekte, en die rol en verlangde uitkomste van elke aspek sal bespreek word. Laastens sal die rol van die riglyne van die Nederduitse Gereformeerde Kerk (NG Kerk) in dié verband, vervat in die publikasie A-Z Handleiding aangaande predikante van die Nederduitse Gereformeerde Kerk (2007), aan die orde kom. Voordat die tema egter verder uitgebou word, is dit eers nodig om twee belangrike terme, naamlik 'predikant' en 'keuring', te verduidelik.

\section{PREDIKANT}

Gerben Heitink (2002:181) omskryf die predikant aan die hand van die terme 'geskiktheid', 'bekwaamheid' en 'bevoegdheid'. Cooke (2007:31) gebruik weer die volgende sirkel om die eenheid en samehang van die verskillende aspekte van die roeping van die predikant aan te dui.

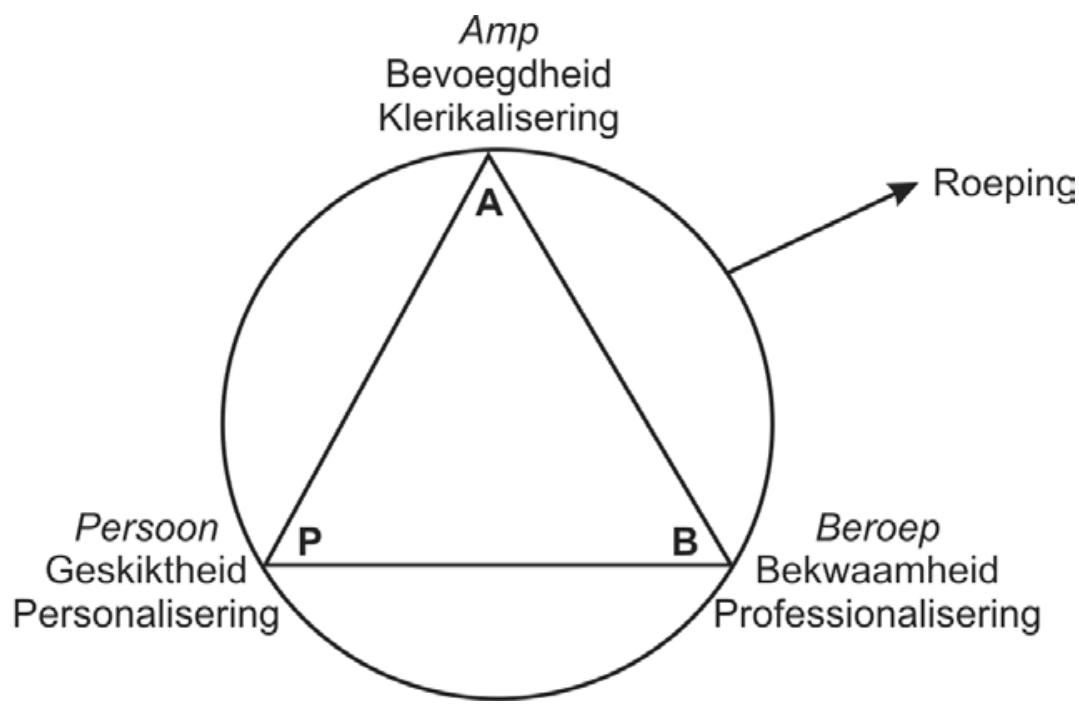

FIGUUR 1

Eenheid en samehang van die roeping van predikante 


\section{Keuring}

Keuring kan beskryf word as die siftingsproses met die oog op goedkeuring van kandidate vir toelating tot die bediening. Die proses moet die bevoegdheid, bekwaamheid en geskiktheid van kandidate vir die bediening bepaal. Keuring is nie daarop gemik om die kandidaat se getuienis oor sy of haar roeping te beoordeel nie, maar ' $n$ positiewe resultaat op genoemde gebiede sal op ' $n$ bevestiging van die kandidaat se getuienis oor sy of haar roeping neerkom.

Dit is belangrik om tussen keuring vir teologiese opleiding, en keuring vir ander beroepe te onderskei. Eersgenoemde is nie 'n enkelvoudige gebeurtenis, byvoorbeeld op grond van matriekpunte, nie, maar ' $n$ proses wat met die aanmelding vir teologiese opleiding begin, en met die toekenning van ampsbevoegdheid (legitimasie) voltooi word. Hierdie omskrywing impliseer dat:

- ' $n$ kandidaat aan die einde van opleiding kan verneem dat hy of sy nie vir die bediening geskik is nie

- aanvanklike geskiktheid kan verander.

Bogenoemde bied ' $\mathrm{n}$ blik op die sensitiewe aard van keuring. Indien die saak nie reg hanteer word nie, kan dit veroorsaak da die kerk diegene wat tot evangelieverkondiging geroepe voel, op ' $n$ wyse hanteer wat die evangelie nie waardig is nie. Voorts kan die kerk arbeidswette oortree en die gevolge daarvan moet dra.

Ten spyte van hierdie sensitiwiteit, durf die kerk egter nie van hierdie saak van keuring wegskram nie. Die vraag is nie of die kerk dit behóórt te doen nie, maar of die kerk kan bekostig om dit nié te doen nie.

Die rol wat die volgende aspekte in die keuring van kandidate vir teologiese opleiding behoort te speel, word kortliks bespreek.

\section{ROEPING}

Malan Nel (2001:99) omskryf 'roeping' as die totale bediening van die predikant - in, aan en deur die gemeente. Die geloofsgemeenskap kan dus as die vocatio particularis van die predikant beskryf word. In die kerk se begrip van die roeping van die predikant, is daar nog altyd tussen die sogenaamde inwendige roeping (vocatio interna) en uitwendige roeping (vocatio externa) onderskei. Bavinck (1967:iv) onderskei op sy beurt tussen die 'vocatio realis', of saaklike roeping, en die 'vocatio verbalis', of woordelikse roeping. Die 'vocatio verbalis' word weer in 'vocatio externa' en 'vocatio interna', 'vocatio particularis' en 'vocatio providentalis' onderverdeel.

Volgens Kleynhans (1984:32) volg die uitwendige roeping deur die gemeente op die inwendige roeping. Dit span as't ware die kroon op die inwendige roeping. Die $A-Z$ Handleiding aangaande predikante van die Nederduitse Gereformeerde Kerk (hierna 'die $A-Z^{\prime}$ ) (Nederduitse Gereformeerde Kerk 2007) stel dit soos volg:

Wat wel anders is in die roeping van ' $n$ predikant is die goedkeuring en legitimering van die geloofsgemeenskap dat hierdie persoon ' $n$ spesifieke taak in die publieke ruimte van die betrokke geloofsgemeenskap vervul.

(Nederduitse Gereformeerde Kerk 2007:5)

Die uitwendige roeping funksioneer onbedoeld tog as ' $n$ soort keuringsmeganisme in die praktyk. Sonder dat enige uitspraak oor die egtheid van enige kandidaat se roeping gemaak word, bevat die Jaarboek van die Nederduitse Gereformeerde Kerke (NG Kerk 2009:322) 'n lys van 196 beroepbare proponente wat voor 30 Junie 2008 reeds beroepbaar was.

Enige poging tot keuring sal daarteen moet waak om die indruk te skep dit ' $n$ 'egtheidstoets' is. In die A-Z (NG Kerk 2007:5) en elders word daar na die 'onderskeiding van die roeping' verwys. Die gebruik van dié uitdrukking, en die verband waarin dit meermale voorkom, plaas die saak van keuring in die raamwerk van begeleiding eerder as toelating. Indien alle betrokkenes dit só verstaan, sal misverstande uit die weg geruim word, en sal die proses ' $n$ pastorale karakter aanneem wat vir sowel kandidate as die geloofsgemeenskap heilsaam sal wees.

\section{BEVOEGDHEID (AMP)}

In die keuringsproses vind die toekenning van ampsbevoegdheid laaste, op grond van die resultate van die ander twee dele van die proses (bekwaamheid en geskiktheid), plaas, en word ' $n$ juridiese element daaraan gekoppel. Aangesien dit die laaste stap is en ook van die sukses van die proses met betrekking tot bekwaamheid en geskiktheid afhang, dra die instansie wat hiervoor verantwoordelik is (die Algemene Regskommissie) ook verantwoordelikheid vir die hele proses. Dit behels sowel die neerlê van beginsels as die monitering van die proses.

Veranderinge in die wêreld waarin die predikant moet werk, bring ook veranderinge in bedieningstyle en -behoeftes mee. Die daarstel van ' $n$ tentmakersbediening en termyngekoppelde poste is van die wyses waarop die NG Kerk daardie veranderinge probeer bestuur. Dít veroorsaak egter dat daar in die kerk 'kategorieë' predikante met verskillende verantwoordelikhede in die gemeente ontstaan, en daarmee saam die vraag of alle predikante dan dieselfde bevoegdheid moet hê. Die beantwoording van hierdie vraag val op die gebied van diegene wat die bevoegdheid moet verleen, en het boonop implikasies vir die bekwaamheid en geskiktheid van die predikant.

Voorts het die groeiende besef van die belang van missionêre kerkwees verreikende gevolge vir die begrip van ampsbevoegdheid. Dit beteken onder meer dat ' $n$ predikant se bevoegdheid nie meer nét met gemeentelike verband te doen kan hê nie (Cooke 2007:70). Die kerk sal dit in haar besinning oor die verlening van ampsbevoegdheid in ag moet neem.

\section{BEKWAAMHEID (BEROEP)}

Wanneer predikante vir werk of sosiale byeenkomste byeenkom, is hulle opleiding dikwels die onderwerp van bespreking. Enige kritiek op die opleiding gaan dikwels oor die gebrek aan 'n verband tussen akademie en praktyk. Dié verskynsel word nie net met die NG Kerk verbind nie. In hierdie verband maak Maré (2005:434) insiggewende opmerkings, bepaald oor die situasie in die Apostoliese Geloofsending (AGS). Alhoewel die kritiek geldig is, moet daarteen gewaak word dat teologiese opleiding ontaard in ' $\mathrm{n}$ tydperk waartydens die kandidaat ' $\mathrm{n}$ stel 'werktuie' ('tools' in die omgangstaal) in die hand gegee word wat hulle weet hoe om te gebruik, maar nie werklik weet hoekom hulle dit gebruik nie.

Wanneer opleiding as ' $\mathrm{n}$ keuringsinstrument gebruik word, moet die gewenste uitkoms van opleiding duidelik gestel word. Hieroor merk Jeroense (2000) op dat die predikant in die eerste plek teoloog behoort te wees - iemand wat wetenskaplike opleiding ontvang het, waarin hy geleer het om verantwoordelik met tekste om te gaan. ' $n$ Teoloog is iemand wat lees - meer bepaald ook religieuse tekste uit die verlede. Hy of sy het geleer om daardie tekste in 'n breër verband te plaas en uit te lê.

Die predikant word ook opgelei om mense se lewensverhale te lees en te interpreteer. Nie net tekste word geëksegetiseer nie, maar ook individuele mense. Dit vind binne die raamwerk van die evangelie, binne die gemeente, plaas. Op grond van hierdie Skrifverklaring, of eksegese, wil die predikant in ' $n$ helpende verhouding met mense tree om hulle geloofs- en lewensvrae te help beantwoord. 
Van Dam (2004:22) omskryf hierdie bekwaamheid as die vermoë om selfstandig (my kursivering) met die Woord om te gaan, in die Christelike tradisie insig te hê, en selfstandig ' $n$ teologiese analise te doen.

Wat die bepaalde elemente betref waarmee teologiese opleiding die predikant moet toerus, is die outeur dit oor die volgende met Van der Ven (1998) eens:

- Kennis: Die vermoë om gestruktureerde inligting narratief en konseptueel te reproduseer.

- Insig: Die vermoë om gestruktureerde inligting narratief en konseptueel te produseer.

- Vaardighede: Die vermoë om, na gelang van die eise van die beroep, metodes en tegnieke in konkrete situasies te gebruik.

- Houding: Die affektiewe, evaluerende ingesteldheid waaroor ' $n$ professionele persoon moet beskik om die werk op 'n gepaste wyse te doen.

(Van der Ven 1998:110)

Die samehang van beroep en geskiktheid moet ook raakgesien en verstaan word. ' $n$ Keuringsbeleid word bepleit waardeur kandidate daartoe gelei word om hul roeping te onderskei. Dít impliseer ook dat geen enkele persoon alles uitstekend hoef te kan doen nie. Dit is duidelik dat ' $n$ roeping ' $n$ roeping tot die totale bediening veronderstel. Dit beteken egter nie dat daar nie ook ruimte is vir wat Heitink (2002:282) 'gematigde spesialisasie' noem nie. Daarmee bedoel hy veral differensiasie en funksionele spesialisasie in ' $n$ gemeente, wat in baie gemeentes reeds die praktyk is. Nel (2004) het die volgende by te voeg:

Die geheel is nie onoorsigtelik nie, maar die behartiging van al die 'komponente' van die geheel is nie meer moontlik nie...'n Kontekstuele verpligting tot alle vorme van bediening verander nog niks aan die beginsel nie. "Roeping tot voltydse bediening, ' $n$ roeping tot alle vorme van bediening in die gemeente, impliseer nie uitmuntendheid in elke vorm van die bediening nie".

(Nel 2004:612)

Dit is egter so dat die professionalisering van die amp van predikant sedert die tweede helfte van die vorige eeu al hoe meer beklemtoon is. Kortom kom dit daarop neer dat daar al meer van ' $n$ predikant verwag word om nie net baie te weet nie, maar ook baie te kan doen. Die predikant moes mettertyd ook 'n deskundige word. Dié tendens kom tans ook in Suid-Afrika voor. Daar kan geen beswaar teen die ontwikkeling gemaak word nie. Trouens, dit is noodsaaklik. Dit is egter ook medisyne met newe-effekte (Heitink 2002). Die newe-effekte blyk in die verhoudings waarin die predikant staan:

Aangesien die klem nou op die funksionaliteit van die verhoudings val, maak dit egte verhoudings moeilik. Dit versterk weer die posisies van 'maghebber' en 'ondergeskikte' in die verhoudings. Tog kan daar ook aangevoer word dat die funksionele aard van die verhoudings juis groter toenadering moontlik maak, mét die nodige behoud van afstand.

(Heitink 2002:204)

\section{Kompetensies}

Diegene wat al oor die kompetensies van die predikant geskryf het, doen dit meestal op grond van hul beskouing van die predikant en pastoraat. Elke skrywer lewer dus ' $n$ bydrae tot die mosaïek van die predikant, maar dit bly ' $n$ mosaïek met vele skakerings. Dié skrywers sluit Adams (1970), Clinebell (1984) en Jentsch (1989) in. Van der Meulen (2004:277) onderskei tussen amptelike, hermeneutiese, kommunikasie- en misterievertolkingskompetensies.

\section{Ampskompetensie}

Die amp is reeds hier bo bespreek. By die predikant is rol, bekwaamheid en persoon baie nou verweef. Die predikant moet ook ' $n$ bepaalde kompetensie hê in die elemente wat sy of haar identiteit bepaal. In die amp moet predikante mense se vertroue geniet. Dat dit deesdae in Suid-Afrika van sowel die kerk as predikant waar is, kan na 'n teenstrydigheid klink, maar is inderdaad so. Daar is baie verhale wat berig oor hoe predikante mense se vertroue misbruik; nogtans bly die vertroue staan (Van Dam \& Eitjes 1994:87-107).

\section{Hermeneutiese kompetensie}

Hierdie kompetensie veronderstel die interpretasie van die verhaal van mense, en die verhaal van God. Dit strek egter ook verder as om die verhale te interpreteer - hulle moet ook met mekaar in verband gebring kan word. 'n Predikant met hierdie kompetensie sal weet wanneer om langer by God se verhaal of die pastorant se verhaal te vertoef.

\section{Kommunikasiekompetensie}

Van der Meulen (2004:279) onderskei tussen intrapersoonlike kommunikasie en interpersoonlike kommunikasie. Intrapersoonlike kommunikasie veronderstel ook die predikant se kommunikasie met God. Hierdie kompetensie behoort ook empatiese luister in te sluit.

\section{Mistagogiese kompetensie}

Met mistagogie word bedoel die inleiding in die geheim van die heil. Dit dui op die vermoë om die mens in hulle omgang met God te begelei, en maak deel uit van geestelike begeleiding (Van der Meulen 2004:280).

Ter aanvulling van hierdie lys, noem Cooke (2007:63) ook integriteit en kreatiwiteit.

\section{Integriteit}

Ezell (1995:83) beskryf integriteit as ' $n$ hoë lewenstandaard wat op 'n persoonlike morele kode berus. Dit swig nie voor die wil van die meerderheid nie. Integriteit is nie reputasie of sukses nie. Dit is die somtotaal van wie die predikant is en van wat hy of sy doen. Die oorsprong van integriteit lê in wie die predikant is, en kom tot uiting in hoe hy of sy leef.

\section{Kreatiwiteit}

Hoe meer gevorderd tegnologie raak, en hoe meer toegang selfs kleiner gemeentes daartoe het, hoe meer sal die predikant moet meeding met ander dinge wat die mense se aandag opeis. Dit impliseer nie dat preke voortaan met behulp van PowerPointaanbiedings moet geskied nie, maar dat daar na nuwe wyses gesoek moet word om die ou boodskap oor te dra, sonder om die boodskap self te verander.

By die predikant kan die 'wie hy of sy is' nie van die 'wat hy of sy doen' geskei word nie. Wanneer die keuringsproses dus die bekwaamheid van die predikant in die oog het, behoort dit ook daaroor te gaan dat kandidate begelei word tot ooreenstemming tussen 'wie hulle is' en 'wat hulle doen'.

\section{GESKIKTHEID (PERSOON)}

Die geskiktheid, of persoon, van die predikant is sowel die mees omstrede as die mees aktuele aspek van die keuringsproses.

Dit is aktueel omdat die persoon van predikante ' $n$ al hoe groter rol in hul bediening speel. Ons leef in ' $n$ al hoe meer geïndividualiseerde samelewing, waarin predikante hul persoon sal moet 'waarmaak'. Mense verwag toenemend inspirerende leierskap, wat ' $n$ baie persoonlike saak is. Wanneer mense verandering verwag, en dit gebeur nie, gryp die samelewing volgens Rendle (1998:35) na een van drie kitsoplossings: mense (people), programme (programs) of beleid (policy). Oor die kitsoplossing van mense sê hy:

The most popular people to change for congregations are the clergy. Persone in beroepe wat geen beskerming bied nie, waar hulle alleen vir die gevolge van hul besluitneming verantwoordelik is, kan die prooi van beroepsuitbranding en depressie word. Met keuring 
word predikante dus al meer op hul persoon beoordeel. Die amp van predikant is, in ' $n$ groter mate as ander beroepe, ' $n$ roeping waar al die persoonlike vermoëns en vaardighede van predikante aan hulle taak gewy word. Predikante behoort outonoom en onafhanklik te kan optree, want daar is baie besluite wat hulle alleen kan neem. Die predikant moet vry wees van eksterne druk, en in staat wees om positief op frustrasies en mislukkings te reageer.

(Cooke 2007:60)

Keuring is sowel aktueel as omstrede. Enige negatiewe uitspraak wat' $n$ keuringsliggaam oor die geskiktheid van die persoon van kandidate maak, sal immers as ' $n$ uitspraak oor die geldigheid van hulle roeping vertolk word. Die menslike sy van die hele saak van roeping is egter ' $n$ voldonge feit. Agter elke persoon wat as kandidaat vir teologiese opleiding aanmeld, sit daar nie net die roepstem van God nie, maar ook ' $n$ mens wat doelbewus besluit het om positief op daardie roepstem te antwoord. In daardie antwoord speel sosiologiese en psigologiese faktore ' $n$ rol.

\section{Sosiologiese faktore}

Sosiologiese faktore het vroeër 'n belangriker rol gespeel. Die predikantsamp was ' $n$ gesogte roeping waarna baie mense gestreef het (Kaptein 1966:143). In Suid-Afrika was die amp van predikant ook dikwels ' $\mathrm{n}$ goeie wegspringplek na die joernalistiek en politiek. Mettertyd het dit egter geblyk dat om sosiologiese faktore die deurslag te laat gee in die besluit om ' $n$ predikant te word, nie meer haalbaar is nie. Dit is juis as gevolg van sosiologiese oorwegings dat die kerk tans nie meer in die moderne wêreld aanvaarbaar is nie. Kotze (1980:293) beskryf die predikant met ' $n$ monopolistiese siening van geestelike diens, as ' $\mathrm{n}$ absurditeit in hierdie wêreld. Dit lei tot ' $\mathrm{n}$ verlies aan realiteit waaraan die ampte en die predikant hulle uiteindelik doodbloei. Deesdae is die neiging dus om sosiologiese faktore te laat vaar en met psigologiese faktore te vervang. Dit sou egter verkeerd wees om summier van alle sosiologiese oorwegings afstand te doen. Die keuringsproses vereis ' $n$ gebalanseerde benadering wat alle menslike faktore in die antwoord op die roeping in aanmerking neem.

\section{Psigologiese faktore}

Vir Oswald (1998:14) was die konfrontasie met sy onderliggende motivering om 'n predikant te word, pynlik. Eerstens het hy predikant geword om sy ouers tevrede te stel (sosiologies). Tweedens het hy dit gedoen om God 'sag te maak'. Hy het homself as ' $\mathrm{n}$ verskriklike sondaar beskou omdat hy sterk seksuele gevoelens gekoester het. Verder het hy ' $n$ behoefte gehad om te voel dat hy nodig is. Wanneer mense hom nodig gehad het, het dit sy roepingsgevoel bevestig. Menslike behoeftes word maklik as God se roepstem beskou. Dit kan weer tot probleme met gemeentelede aanleiding gee. Alle predikante kan iets hiervan in hulle eie bediening herken. Vir Oswald (1998:15) lê die oplossing daarin om roeping te sien as ' $n$ uitnodiging om vry en heel te word. Die roeping na ' $n$ gemeente behoort as bediening vir God, en nie net as bediening aan mense nie, beskou te word. Die predikant se eerste verantwoordelikheid teenoor ' $n$ gemeente, volgens Oswald (1998:15), is om 'n vreugdevolle, geredde mens te wees. Predikante se ervaring toon egter dat baie jare in ' $n$ gemeente daardie vreugde kan laat taan.

Vanuit 'n psigologiese perspektief, werk Rulla, Imoda \& Ridick (1988:6) met konsepte soos die bewuste 'ideale self', en die bewuste óf onbewuste 'werklike self'. Hier gaan dit oor wat ' $n$ individu begeer om te wees, en wat hy werklik is. Ten grondslag hieraan lê waardes, houdings en behoeftes.

- Waardes: Die ideale vir die lewe wat die persoon wil leef.

- Houdings: 'n Geneigdheid tot aksie; meer spesifiek as waardes.

- Behoeftes: Moderne sielkunde het ongeveer 20 grondliggende menslike behoeftes uitgewys, waaronder affektiewe afhanklikheid, seksualiteit, outonomiteit, kennis, endiesmeer. Hierdie behoeftes word in houdings geopenbaar (Rulla et al. 1988:9).

Sommige van dié behoeftes is in stryd met die grondliggende waardes van die bediening. Dus ontstaan die moontlikheid van teenstrydigheid tussen die ware self en die ideale self. Rulla, Imoda \& Ridick (1988:8) onderskei vier soorte ooreenstemming of teenstrydigheid tussen waardes, houdings en behoeftes:

- Sosiale ooreenstemming: Wanneer ' $n$ behoefte in ooreenstemming is met die waardes en houdings van die individu. Dit word 'sosiaal' genoem, want die persoon is sosiaal goed aangepas.

- Psigologiese ooreenstemming: Persone se behoefte is in ooreenstemming met hulle waardes, maar nie noodwendig met hulle houdings nie, soos wanneer hulle graag ander wil help, maar hetsy bewus of onbewus, 'n aggressiewe of egoïstiese houding weerspieël. $\mathrm{Al}$ is hulle dus vanweë hulle houding dalk sosiaal wanaangepas, is hulle psigologies wel in pas.

- Psigologiese teenstrydigheid: Die behoefte is in stryd met die waarde of houdings. Wanneer sulke persone byvoorbeeld onbewus hulp van ander benodig, neig hulle houding in die teenoorgestelde rigting - hulle help ander. Hulle is dus op die oog af goeie gelowiges, maar is psigologies teenstrydig.

- Sosiale teenstrydigheid: ' $n$ Onbewuste behoefte is in stryd met die waardes van die bediening, en die persoon se houding gee eerder gehoor aan die behoefte as die waardes. So kan 'n onbewuste behoefte aan affektiewe afhanklikheid tot houdings lei wat in stryd is met die bediening, soos ' $n$ voortdurende soeke na vriendskap en aanvaarding.

Dit roep die volgende vrae op:

Tree mense tot die bediening toe oor wat hulle bewus van hulleself dink, of die persoonlike ideale waarna hulle bewus streef? Rulla, Imoda \& Ridick (1988:74) se studie het getoon dat mense hulle keuses op persoonlike ideale en ' $n$ idealistiese beeld van die instelling, eerder as op bewuste kennis van persoonlike eienskappe, grond.

Behoort die uitgesproke motivering waarom persone tot die bediening toetree voor die voet aanvaar te word, of behoort sekere onbewuste motiverings ook in aanmerking geneem te word? Rulla, Imoda \& Ridick (1988:84) bevind dat die motiewe nie net aanvaar kan word nie. Vir baie is die ideaal op grond waarvan hulle hulle keuses maak, ongeldig as gevolg van onbewuste teenstrydighede. As die bewuste motivering nie die volle motivering is nie, watter uitwerking het dit op diegene wat tot die bediening toetree (die intra-psigiese dinamiek)?

Bly hierdie intra-psigiese dinamiek voortbestaan in diegene wat in die bediening aanbly? In dié verband beweer Rulla, Imoda \& Ridick (1988:99) dat weinig mense ná vier jaar in die bediening ' $n$ vlak van volwassenheid bereik waar hulle innerlike konflik suksesvol kan hanteer. Persoonlike ontwikkeling en ontwikkeling in die bediening is verweef.

Beïnvloed psigodinamiek ook diegene wat die bediening verlaat, en die effektiwiteit van diegene in die bediening? Baie persone wat tot die bediening toetree, het persoonlikheidsgebreke wat, hoewel nie patologies nie, hulle tog kwesbaar maak in hulle motiewe vir waarom hulle die bediening gekies het. Hierdie gebreke bestaan voor opleiding reeds, en is dikwels onbewus. Dit bly dus in die persoon van die predikant voortbestaan, en het ongetwyfeld ' $n$ invloed op die bediening van die predikant.

Dit word dus duidelik dat die een of ander vorm van keuring met betrekking tot die geskiktheid van die persoon van die kandidaat vir teologiese opleiding onontbeerlik is. Die beoogde uitkoms van die keuringsproses egter nie om net die bestes toe te laat of om 'ongewenste' kandidate weg te wys nie, maar om kandidate te begelei om sowel hulle roeping as hulle plek in die liggaam van Christus te onderskei. So ' $n$ keuringsbeleid sal ook moet ag slaan op die Bybelse gedagte (2 Kor 3:6; Fil 2:13) dat 
God nie noodwendig die beste en bekwaamste roep nie, maar dat God dié wat God roep bekwaam maak vir hul opdrag.

\section{Keuringsinstrumente}

Met die oog op die ontwikkeling van keuringsinstrumente het die skrywer ' $n$ 'battery' toetse afgelê om, selfs ná 25 jaar in die bediening, sy geskiktheid vir die bediening te probeer bepaal. Die 'battery' toetse het die 16 PF-vraelys, die Myers-Briggsvraelys op vlak 2, en 'n vraelys oor emosionele intelligensie ingesluit. Die resultaat was nie ' $n$ eenvoudige ja of nee ten opsigte van die bediening nie, maar eerder potensiaal vir die bediening, maar ook swak plekke en sake wat aandag verg as die persoon tot selfverwesenliking wil kom. 'n Ondersoek van die toetsresultate het getoon dat die toetse van waarde is om kandidate te help om hulle roeping te onderskei. Dit bevestig dat die kerk bruikbare materiaal vir keuring het, wat reeds met welslae in die praktyk gebruik word.

Indien die doel van die keuringsproses is om roeping te onderskei en te verstaan, is dit van die allergrootste belang dat dit met begeleiding gepaardgaan.

\section{DIE A-Z HANDLEIDING AANGAANDE PREDIKANTE VAN DIE NEDERDUITSE GEREFORMEERDE KERK}

Die Handleiding was die resultaat van 'n opdrag wat die Algemene Sinode van die NG Kerk in 2004 aan 'n taakgroep kundiges gegee het. Die beleidsdokument is in 2007 vir goedkeuring aan die Algemene Sinode voorgelê is. Nog voordat die verslag voor dié Sinode kon dien, het dit al opslae gemaak, en is die moontlikheid selfs genoem dat individuele sinodes oor die dokument uit die NG Kerk kon wegbreek (Jackson 2007a:4). Die besware teen die dokument het onder meer ingesluit dat dit ' $n$ manier is om funksies wat tot kerkrade behoort, soos om 'n predikant te orden, aan 'n gesentraliseerde sinodale instelling toe te ken. Die sterk gevoel van die sinode van Noord-Kaapland téén die dokument onderstreep die uiteenlopende standpunte in die kerk. Die verslag is uiteindelik wel goedgekeur, maar sekere dele, onder meer dié oor die behoud van bevoegdheid, is vir verdere studie terugverwys.

'n Beoordeling van die $A-Z$-verslag moet in ag neem dat dit 'n dinamiese dokument is wat beslis in die toekoms gaan verander (NG Kerk 2007:2). Daarom behoort geen finale beslissing oor die dokument gemaak te word nie.

Die $A$-Z-verslag erken die belang van die predikant vir die NG Kerk, en erken dat holistiese denke oor die predikant nie meer uitgestel kan word nie (NG Kerk 2007:2). Dit is die eerste dokument wat aan die NG Kerk 'n werklik omvattende benadering tot die kerk se predikante aan die hand doen, en die saak van keuring kom ook daarin aan die orde (NG Kerk 2007:10).

'n Belangrike ontwikkeling in die $A-Z$ is die duidelike rolle wat dit aan die plaaslike gemeente en die Ring toeken. Die student se tuisgemeente word die eerste plek van aanmelding vir die kandidaat. Die gemeente se funksie word soos volg uiteengesit:

Gemeentelike keuring van voornemende studente hou rekening met die volgende:

- Die karakter van die leier (dit wat vertroue skep by volgelinge). Hier word gedink aan morele sake wat belangrik is soos eerlikheid, integriteit, billikheid, empatie, diensgerigtheid, gebedslewe, vertroue op God, emosionele intelligensie.

- Die oortuiging van die leier (dit wat 'n gemeente kan help om doel en visie te onderskei). Reflektiewe leierskap is belangrik.

- Kompetensie van die leier (dit wat 'n gemeente kan help om normale vrese te hanteer en konflikte te kan help oplos).

- Onderskeiding van roeping tot die bediening in gesprek met die voornemende student.
- Instemming met die NG Kerk se verstaan van die beroep van die predikant soos in die beleid van die Algemene Sinode uitgedruk.

- 'n Skriftelike getuienis van die voornemende student wat 'n inwendige roeping onderskei. Hierdie getuienis bevat:

- ' $n$ Verduideliking van sy/haar verstaan van sy/haar roeping.

- 'n Persoonlike getuienis oor persoonlike geloofsekerheid en persoonlike ervaring van die genade van God.

- 'n Verduideliking van die persoon se oortuiging oor wat dit beteken om teologiese opleiding in die Gereformeerde leer te ontvang.

- 'n Getuienis oor die persoon se persoonlike lewensverhaal, wat insluit sy/haar sorg vir geestelike, fisiese en emosionele gesondheid.

- 'n Getuienis oor sy/haar verstaan van die inhoud van 'n predikant se dienswerk, wat insluit sy/haar bewussyn van sy/ haar gawes en

groeigeleenthede en ook sy/haar bewussyn van die kerk se taak in die wêreld.

- 'n Onderneming om hom/haar neer te lê by die toesighoudingsproses wat die kerkverband daarstel.

(NG Kerk 2007:11)

Die Ring kry die volgende funksie:

- die inhoud van die kerkraadsverslag en alle dokumentasie deur die voornemende student voorsien

- voortgaande gesprek oor roepingsonderskeiding en roepingsinhoud

- persoons-en roepingsontwikkeling

- moontlike gespesialiseerde roepingsbegeleiding en psigologiese evaluering

- beroepsgeleenthede

- $\quad$ instemming met die NG Kerk se verstaan van die beroep van die predikant soos in die beleid van die Algemene Sinode uitgedruk.

Op grond van sodanige onderhoude word 'n goedgemotiveerde verslag en aanbeveling aan die betrokke kuratorium voorsien.

(NG Kerk 2007:12)

Hierdie aanhalings toon dat die $A-Z$ in 'n hele aantal opsigte ' $n$ baie belangrike ontwikkeling is. Die saak van keuring word hiermee amptelik deel van die kerk se beleid oor predikante. Die hele kerk raak betrokke by die proses; nie net 'n kommissie wat verwyderd is van die gemeente waar die predikant uiteindelik moet gaan werk nie. Die dokument plaas die hele saak van keuring binne die raamwerk van 'roeping', en nie 'toelating' nie. Sodoende verkry keuring 'n pastorale karakter. Cooke (2007:113) noem dit 'die totale kompleks van aktiwiteite van die hele kerk'. Oor die betekenis van die uitdrukking 'hele kerk', meen Cooke (2007:113) dat al die gestaltes (vergaderings) van die kerk, naamlik kerkraad, Ring, plaaslike sinode en Algemene Sinode, by die versorging en begeleiding van predikante betrokke behoort te wees. Dit is belangrik dat elke vergadering sal weet wat sy bepaalde rol in hierdie verband is. Hierdie rol sal deur middel van besluite van die Algemene Sinode, en uiteindelik deur formulering in die kerkorde, neergelê moet word. Die $A-Z$ voor dié proses aan, maar die kerk mag nie volstaan met wat reeds bereik is nie. Die proses is nog nie voltooi nie.

\section{BEVINDING}

Die keuring van kandidate met die oog op teologiese opleiding is 'n sensitiewe en omstrede saak, wat vererger word as die proses simplisties beskou word as ' $n$ beoordeling van die egtheid van die voornemende kandidaat se roeping. Die artikel toon dat die profiel van die predikant, benewens die roeping, ook uit die amp (bevoegdheid), beroep (bekwaamheid) en persoon (geskiktheid) bestaan. Die keuringsproses behoort oor al hierdie aspekte van die predikant te handel. So 'n wyer fokus, om ook die ander aspekte van die predikantsprofiel in te sluit, vergemaklik nie die proses nie, maar is noodsaaklik vir beter begrip vir die welstand van die predikant en die kerk. Keuring vir teologiese opleiding is nie ' $n$ eenmalige gebeurtenis met die oog op toelating nie, maar is deel van die proses wat begin by die aanmelding by die plaaslike gemeente en voltooi word wanneer ampsbevoegdheid deur die kerk aan die kandidaat verleen word. 
Die hoofdoel van die keuringsproses is nie om die 'beste' kandidate met die oog op toelating te vind nie, maar om kandidate tot die onderskeiding van hul roeping sowel as hulle plek in die liggaam van Christus te begelei.

Die $A-Z$ lewer ' $n$ belangrike rigtinggewende bydrae tot hierdie proses.

\section{LITERATUURVERWYSINGS}

Adams, J., 1970, Competent to counsel [Bevoeg om te beraad], Presbyterian and Reformed Publishing, Phillipsburg, NJ.

Bavinck, H., 1967, Gereformeerde dogmatiek, vol. IV, Kok, Kampen.

Clinebell, H., 1984, Basic types of pastoral counselling: Resources for the ministry of healing and growth [Basiese vorme van pastorale berading: Hulpbronne vir die bediening van genesing en groei], SCM Press, London.

Cooke, F.T., 2007, ‘Die gebruik van die pastor pastorum in die pastorale versorging van predikante van die NG Kerk', ongepubliseerde DD-verhandeling, Fakulteit Teologie, Universiteit van Pretoria.

Ezell, R., 1995, Ministry on the cutting edge [Ministrie op die voorpunt], Alban Institute, Washington DC.

Heitink, G., 2002, Biografie van de dominee [Biografie van die dominee], Ten Have, Kampen.

Jackson, N., 2007a, 'NGK besin dán oor skeur', Beeld, 3 Mei, p. 4.

Jackson, N., 2007b, 'Noord-Kaap bly NG', Beeld, 10 Mei, p. 12.

Jentsch, W., 1989, Der Seelsorger [Die pastor], Brendow Verlag, Moers.

Jeroense, J., 2000, 'De Predikant is theoloog! [Die predikant is 'n teoloog]', Woord en Dienst 49/24.

Kaptein, R., 1966, De Predikant, zijn plaats en zijn taak in een nieuwe wêreld [Die predikant se plek en taak in die nuwe wêreld], Poal en van Gennep, Amsterdam.
Kleynhans, E.P.J., 1984, Gereformeerde kerkreg, vol. 2, NG Kerkboekhandel, Pretoria.

Kotze, E.C.S., 1980, 'Wat behoort die predikant te doen?', ongepubliseerde DD-proefskrif, Fakulteit Teologie, Universiteit van Pretoria.

Maré, L.P., 2005, 'AGS pastore se belewenis van hulle teologiese opleiding', Verbum et Ecclesia 26(1), 432-458.

Nederduitse Gereformeerde Kerk, 2007, A-Z Handleiding aangaande predikante van die Nederduitse Gereformeerde Kerk, NG Kerk, Pretoria.

Nederduitse Gereformeerde Kerk, 2009, Jaarboek van die Nederduitse Gereformeerde Kerke, Bybelmedia, Wellington.

Nel, M., 2001, Ek is die verskil, CLF, Bloemfontein.

Nel, M., 2004, 'Publieke pastorale leiers: Roeping, werwing en keuring', Verbum et Ecclesia 25(2), 584-618.

Oswald, R.M., 1998, Clergy self-care [Predikante self sorg], Alban Institute, Washington DC.

Rendle, G.R., 1998, Leading change in the congregation [Vooraanstaande veranderinge in die gemeente], Alban Institute, Washington DC.

Rulla, L.M., Imoda, F. \& Ridick, J., 1988, Psychological structure and vocation [Sielkundige struktuur en roeping], Gregorian University Press, Rome.

Van Dam, G., 2004, Dichter bij het onuitspreeklijke: Over geestelijke begeleiding voor en door pastores [Nader aan die onuitspreeklike: Aangaande geestelike begeleiding vir en deur pastors], Ten Have, Baarn.

Van Dam, G. \& Eitjes, M., 1994, Een pastor moet je toch kunnen vertrouwen ['n Pastor moet jy kan vertrou], Meinema, Zoetermeer.

Van der Meulen, H.C., 2004, De pastor als reisgenoot: Pastoraaltheologische gedachten over geestelijke begeleiding [Die pastor as reisgenoot: Pastoraal-teologiese gedagtes oor geestelike begeleiding], Boekencentrum, Zoetemeer.

Van der Ven, J.A., 1998, Education for reflective ministry [Onderwys vir reflektiewe bediening], Peters, Leuven. 